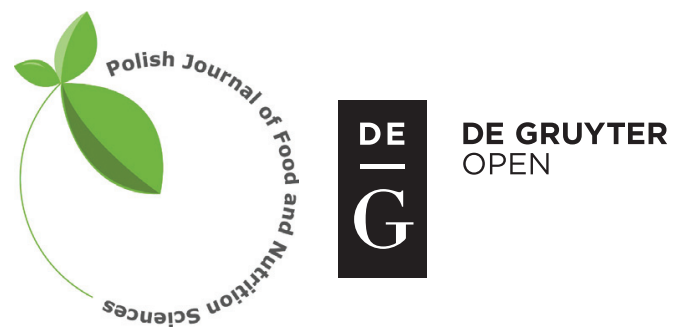

Pol. J. Food Nutr. Sci., 2016, Vol. 66, No. 1, pp. 31-36 DOI: $10.1515 /$ pjfns-2015-0051 http://journal.pan.olsztyn.pl

Mini Review

Section: Nutritional Research

\title{
Identification of Bovine, Pig and Duck Meat Species in Mixtures and in Meat Products on the Basis of the mtDNA Cytochrome Oxidase Subunit I (COI) Gene Sequence
}

\author{
Anita Spychaj ${ }^{1 *}$, Marlena Szalata², Ryszard Stomski², Edward Pospiech ${ }^{1}$ \\ 'Institute of Meat Technology, Poznań University of Life Sciences, ul. Wojska Polskiego 31, 60-624 Poznań, Poland \\ ${ }^{2}$ Department of Biochemistry and Biotechnology, Poznań University of Life Sciences, ul. Dojazd 11, 60-632 Poznań, Poland
}

Key words: PCR assay, mitochondrial DNA, meat species identification, meat products

The aim of this study was to develop a method using PCR and self-designed primers on the basis of the mtDNA cytochrome oxidase subunit I (COI) gene sequence to enable direct identification of the meat of three species of animals, i.e. bovines, pigs and ducks, in the single type sample, in meat mixtures and meat products. The mixtures comprised up to six meat species including apart from beef, pork and duck also chicken, turkey and goose meat. The obtained results indicate the possibility of qualitative identification of the aforementioned meat species in all types of investigated food products. The maximum length of PCR products did not exceed $300 \mathrm{bp}$, which was supposed to favour the amplification of DNA from meat products which are usually thermally processed and/or exposed to high pressure. PCR primers hybridised selectively with bovine, pig and duck DNA, showing total species specificity.

\section{INTRODUCTION}

The analytical methods based on DNA analysis belong to the group of the most appreciated methods in research on the verification of the authenticity of meat species. It results from the specific character of the structure of deoxyribonucleic acid (DNA) particles and the possibility of using the information included in them [Karabasanavar et al., 2011].

The researchers concerned with species identification pay increasing attention to the cytochrome oxidase subunit I (COI) gene. In 2003, the gene was selected for the identification of global biodiversity of eukaryotic organisms in the DNA barcoding method [Herbert et al., 2003].

Wong \& Hanner [2008] used the barcoding method in their studies to prove the adulteration of the fish known as red snapper (Lutjanus campechanus) with other species of fish or the adulteration of white tuna meat with tilapia meat. The method which uses the 'biological tag' also proved to be effective in differentiating bovine meat (Bos taurus) and southern reedbuck meat (Redunca arundinum) [Dalton \& Kotze, 2011]. Universal primers were used to amplify a fragment of the bovine and chicken $\mathrm{COI}$ genes, thus indicating the usefulness of this method for the differentiation of meat species [Dawnay et al., 2007]. However, it is noteworthy that the barcoding method, which uses DNA sequencing, is more suitable for the analysis of samples with individual meat types rather than complex mixtures. In the latter case, when, e.g.

\footnotetext{
* Corresponding Author: Tel.: +48-61-848-7263;

E-mail address: aspychaj@up.poznan.pl (Drinż. Anita Spychaj)
}

Sanger sequencing is used, it is necessary to conduct additional procedures, i.e. to clone PCR products [Pereira et al., 2008].

Feligini et al. [2005, 2007] used bovine-specific PCR primers, which were designed on the basis of the COI gene sequence, and made a qualitative and quantitative identification of cow's DNA in mozzarella cheese.

Haider et al. [2012] used COI sequences and seven restrictive endonucleases to identify raw bovine, chicken, turkey, sheep, pig, camel and donkey meat with the method assessing the restriction fragments length polymorphism (PCR-RFLP). In spite of the fact that the method using the $\mathrm{COI}$ gene enabled the differentiation of even such closely related species as the cow and buffalo or the chicken and turkey, its application may sometimes lead to false results. This may be related to the possibility of incomplete hydrolysis of restriction sites because of the enzymes used for investigations or to the occurrence of mutations in restriction sites within the species under investigation [Pereira et al., 2008; Ballin et al., 2009; Gil, 2007].

Furthermore, it is not always possible to obtain a long PCR product (700 bp) with recognisable sites to restriction enzymes, as the PCR-RFLP technique requires, from the DNA of meat products which were heated [Fajardo et al., 2006, 2010; Eaqub et al., 2012].

Therefore, the aim of our work was to create three species-specific primer pairs based on the COI gene structure. These primers would enable direct identification of meat from three species of animals, i.e. bovines, pigs and ducks, in the single meat sample, in meat mixtures and meat products. The study included the meat from three species of animals, which belong 
to the group of animals the most often slaughtered on an industrial scale in Poland [Statistical Yearbook of Agriculture, 2013].

\section{MATERIALS AND METHODS}

\section{Meat samples}

Apart from bovine meat (Bos taurus), pig meat (Sus scrofa f. domestica) and duck meat (Anas platyrhynchos), chicken meat (Gallus gallus), turkey meat (Meleagris gallopavo) and goose meat (Anser anser) samples were also collected. As far as the bovine and pig meat is concerned, the samples were collected from the longest lumbar muscle $(\mathrm{m}$. longissimus lumborum), whereas poultry meat samples were collected from the pectoral muscle ( $m$. pectoralis). On collection, the research material was placed in sterile test tubes and stored at a temperature of $-80^{\circ} \mathrm{C}$ until DNA was isolated.

\section{Meat mixtures}

Twenty three meat mixtures were prepared for the research. Twenty one of them consisted of two meat components (Table 1).

The other two meat mixtures had the following qualitative and quantitative compositions: $20 \%$ beef (B), $20 \%$ pork (S), $20 \%$ chicken meat (C), 20\% turkey meat (T), 10\% duck meat (D), $10 \%$ goose meat $(\mathrm{G})$ the first one, and $25 \% \mathrm{~B}, 25 \% \mathrm{~S}$, $25 \%$ C, $25 \% \mathrm{~T}$ the second one.

\section{Meat products}

The research also included an analysis of seventeen meat products purchased in chain stores. The following commercial meat products were investigated: medium minced, smoked, the Polish raw sausages (sample 1 and 16 - pork);

TABLE 1. The qualitative and quantitative composition of meat mixtures.

\begin{tabular}{c|c|c|c|c|c}
\hline S:B & B:S & C:D & T:S & D:S & G:C \\
\hline S:C & B:C & C:B & T:C & D:T & - \\
S:T & B:G & C:S & - & - & - \\
S:D & B:T & C:T & - & - & - \\
S:G & B/S & C/S & - & - & - \\
- & - & C/B & - & - & -
\end{tabular}

Individual types of meat are abbreviated with the following letters: $\mathrm{S}$ - pork, $\mathrm{B}$ - beef, $\mathrm{C}$ - chicken meat, $\mathrm{T}$ - turkey meat, $\mathrm{D}$ - duck meat, $\mathrm{G}$ - goose meat. The meat proportions were 9:1 (abbreviations separated with ,:") or 1:1 (abbreviations separated with „/"). cut, smoked and cooked frankfurters (sample 2, 5, 6- pork), (sample 3 - turkey meat, pork and cheese addition), (sample 4 - pork and milk protein addition), (sample 8 - chicken meat, pork fat), (sample 9 - pork, chicken, turkey meat); raw, medium minced and smoked Frankfurter sausages (sample 7 pork); medium minced, smoked and roast sausage (sample 10 - pork, beef); coarsely minced, smoked, cooked, slightly dried 'Krakov' sausage (sample 11 - pork, beef); finely minced, raw, smoked, slightly dried salami (sample 12, 13 - beef, pork, pork fat); sterilised canned product - duck terrine (sample 14 - duck fat and meat, poultry liver) and goose rillettes (sample 15 - goose meat, pork, pork fat); medium minced, smoked, cooked, slightly dried 'Kabanos' sausage (sample 17 - goose, pork, turkey meat).

\section{DNA isolation}

DNA was isolated from raw animal tissue, mixtures and meat products by means of the PureLinkTM Genomic DNA kit (Invitrogen, Carlsbad, CA, USA), according to the methodology provided by the manufacturer. The DNA was stored for a short time at a temperature of $+4^{\circ} \mathrm{C}$ and then frozen at $-20^{\circ} \mathrm{C}$.

\section{Primers design}

Species-specific primers for the identification of bovine, pig and duck meat were designed on the basis of nucleotide sequences of the COI gene acquired from GenBank from the NCBI base (National Center for Biotechnology Information, Bethesda, MD, USA) and Primer3 program application (Table 2). The primers were synthesised with TIB MOLBIOL (Syntheselabor GmbH, Berlin, Germany).

\section{Species-specific PCR}

The total volume of the mixture for the PCR was $20 \mu \mathrm{L}$. Each time it contained 40 ng DNA, $2 \mu \mathrm{L} 10 \times$ concentrated buffer for the PCR (Sigma, Saint Louis, MO, USA), $1 \mu \mathrm{mol} / \mathrm{L}$ of each pair of primers (TIB MOLBIOL), $0.25 \mathrm{mmol} / \mathrm{L} \mathrm{dNTP}$ (Sigma) and $0.03 \mathrm{U}$ of Taq DNA polymerase (Sigma).

As far as the primers for the identification of duck meat are concerned, reagents provided by the Invitrogen company were used in the study. The PCR sample contained $2 \mu \mathrm{L} 10 \times$ concentrated buffer for the PCR without $\mathrm{MgCl}_{2}$ (Invitrogen), $5 \mathrm{mmol} / \mathrm{L} \mathrm{MgCl}_{2}$ (Invitrogen), $1 \mu \mathrm{mol} / \mathrm{L}$ of each pair of primers (TIB MOLBIOL), $0.25 \mathrm{mmol} / \mathrm{L} \mathrm{dNTP} \mathrm{(Sigma)}$ and $0.03 \mathrm{U}$ of Taq DNA polymerase (Sigma).

TABLE 2. The pairs of PCR primers designed on the basis of the cytochrome oxidase subunit I gene fragment.

\begin{tabular}{|c|c|c|c|c|c|}
\hline Species & Primer name & $\begin{array}{l}\text { Accession } \\
\text { number }\end{array}$ & $\begin{array}{l}\text { Primer sequence } \\
5^{\prime}-3^{\prime}\end{array}$ & $\begin{array}{l}\text { Amplified } \\
\text { fragment }\end{array}$ & $\begin{array}{l}\text { Size of PCR } \\
\text { product (bp) }\end{array}$ \\
\hline Bovine & $\begin{array}{l}\text { BTCOIF11 } \\
\text { BTCOIR11 }\end{array}$ & AF492351 & $\begin{array}{l}\text { GAACTCTGCTCGGAGACGAC a } \\
\text { GGTACACGGTTCAGCCTGTT }\end{array}$ & $134-388$ & 255 \\
\hline Pig & $\begin{array}{l}\text { SSCOIF } 11 \\
\text { SSCOIR11 }\end{array}$ & NC_012095.1 & $\begin{array}{l}\text { GGAGCAGTGTTCGCCATTAT } \\
\text { TTCTCGTTTTGATGCGAATG }\end{array}$ & $1150-1443$ & 294 \\
\hline Duck & $\begin{array}{l}\text { APCOIF } 11 \\
\text { APCOIR11 }\end{array}$ & L22480 & $\begin{array}{l}\text { TAATTGGCACAGCACTCAGC } \\
\text { TTATCAGGGGGACCAATCAG }\end{array}$ & $86-262$ & 177 \\
\hline
\end{tabular}

a The forward primer, which is specific to the DNA of bovine's with identical sequence was earlier applied by Feligini [2005, 2007]. 
The polymerase chain reaction was conducted by means of a peqSTAR thermocycler (PEQLAB, Erlangen, Germany) using the following amplification profile: initial denaturation at $95^{\circ} \mathrm{C}$ for $9 \mathrm{~min}$, followed by 30 cycles each of denaturation at $94^{\circ} \mathrm{C}$ for $1 \mathrm{~min}$, annealing at $60^{\circ} \mathrm{C}$ (for bovine), at $59^{\circ} \mathrm{C}$ (for pig), at $71^{\circ} \mathrm{C}$ (for duck) for $1 \mathrm{~min}$, extension at $72^{\circ} \mathrm{C}$ for $3 \mathrm{~min}$. The final extension was at $72^{\circ} \mathrm{C}$ for $10 \mathrm{~min}$.

The obtained PCR products were separated in $1 \%$ agarose gel for $45 \mathrm{~min}$ at a voltage of $100 \mathrm{~V}$ (Power PAC 300, Bio-RAD, Hercules, CA, USA). Sizes of DNA amplification products were identified using a PCR 100 bp Low Ladder (Sigma) size marker. The results of the separation were observed by means of a G:Box transilluminator (Syngene, Frederik, MD, USA).

\section{PCR product sequencing}

The PCR products were sequenced by means of the cyclic method with the use of capillary electrophoresis and a MegaBACE apparatus (General Electric, USA). Before sequencing, the PCR products were cleaned with a $7.5 \mathrm{~mol} / \mathrm{L}$ ammonium acetate and ethanol solution from the remains of the polymerase, buffer, primers and nucleotides. The obtained DNA sequences were analysed by application of ChromasPro software (Technelysium Pty Ltd) and then their homology was compared with the reference sequences using the BLAST program (NCBI).

\section{RESULTS AND DISCUSSION}

The first step of the study involved tests of PCR primers with DNA extracted from single raw meat samples (beef, pork, duck, chicken, turkey and goose meat). All the primers designed on the basis of the COI gene were proved to exhibit specificity for the DNA from three species of animals, i.e. bovines, pigs and ducks, giving PCR products with intended size only with DNA for which amplification was created (data not shown).

The fact that the designed pairs of primers amplified the species-specific fragment of the COI gene was confirmed by the result of sequencing of the obtained PCR products. The sequencing of nucleic acids enables determination of the primary DNA structure and provides an answer to the question which gene fragment was amplified in the PCR [Kalak et al., 2004; Sambrook \& Russell, 2011].

The obtained DNA sequences were analysed by means of the ChromasPro program. Then they were compared with the reference sequences for individual animal species on the basis of which the PCR primers were designed. The results of the analysis confirmed the fact that all the three pairs of PCR primers, i.e. those designed for the amplification of bovine, pig and duck DNA, hybridised with the fragment of the COI gene.

The comparison of the sequences obtained from the PCR product which was formed as a result of the amplification of the DNA with the primers for bovines (BTCOIF11 and BTCOIR11) and pigs (SSCOIF11 and SSCOIR11) with the reference sequences proved their identity in $100 \%$.

The comparison of the nucleotide sequence of the PCR product formed as a result of the use of primers for the duck
(APCOIF11 and APCOIR11) with reference sequences proved $98 \%$ similarity between them. The absence of $100 \%$ compatibility between the sequences obtained from the sequencing of the duck PCR products with reference sequences may have been related to certain intraspecies differences. It is most likely that the COI gene sequences which were used to design the duck primers came from different duck breeds than those from which the research material was acquired.

Next, the PCR primers were tested on raw meat mixtures. The presence of DNA from different meat species in one sample may disturb the formation of PCR products. The research conducted by Iwobi et al. [2011] proved that it was difficult to detect the chicken or turkey meat in a sample where its content was lower than $0.5 \%$ due to the dominance of pork and beef. On the other hand in the studies carried out by Partis et al. [2000], PCR primers preferred to amplify the DNA sequence a small amount of which was present in the mixture. This observation referred to the primers used in the PCR-RFLP technique, where one pair favoured the amplification of the pig DNA, only $1 \%$ of which was present in the mixture, whereas the other one preferred the amplification of the bovine DNA over other species. Also Dawnay et al. [2007] observed that it was impossible to identify the bovine or chicken DNA, which had considerable quantitative preponderance in the mixture (10:1) over the human DNA.

The results of the analysis revealed that all the three pairs of PCR primers designed to amplify the bovine, pig and duck DNA correctly identified these meat species in the meat mixtures. Each of the pairs of primers enabled the amplification of the DNA from the meat of which $10 \%$ could be found in the mixture. This reaction was also observed for the duck primers in the six-component mixture (data not shown).

The last and most demanding stage of the research was to test the designed set of primers and the established PCR thermal profile on the DNA acquired from meat products. The species identification based on nucleotide sequences always requires that an appropriate quality and quantity of DNA specimens should be acquired. It is particularly difficult in the case of processed food. During the extraction of DNA from meat products to specimens such compounds as Maillard reaction products, milk proteins, fat, glycogen, collagen, iron, cobalt, etc. may also be transferred. These compounds inhibit DNA amplification and may significantly affect the result of the analysis [Cammá et al., 2012; Wilson, 1997]. Additionally, apart from the target DNA to be investigated, the sample under analysis may also contain the DNA of other origin, e.g. from bacteria, plants, animals [Teletchea et al., 2005]. Besides that, some enzymes, e.g. those which are present in soy specimens, may cause DNA degradation [Musto, 2011]. That is why it is necessary to remember that the absence of the product of DNA amplification after the PCR may be related not only to the insufficient amount or absence of DNA from the sample, but also to the inhibiting effect of contaminants in the specimen under analysis. Therefore, it is a key element of the experiment to remove all PCR inhibitors [Teletchea et al., 2005; Musto, 2011].

The outcome of amplification is significantly influenced not only by the DNA isolation procedure adequate to the biological material under analysis but also by the technological 


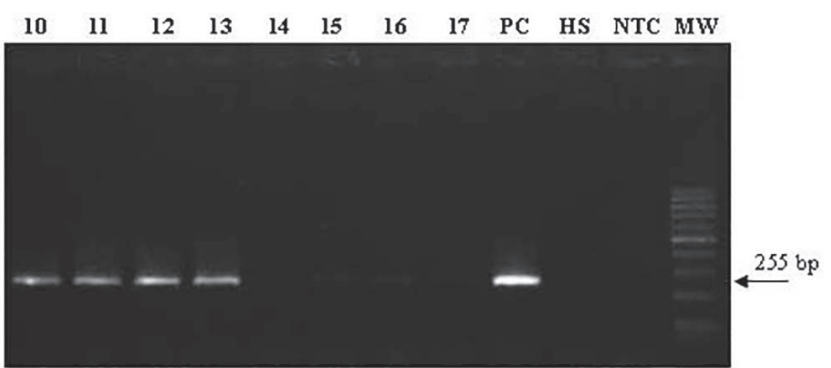

FIGURE 1. The electrophoretic separation of PCR products in $1 \%$ agarose gel. A polymerase chain reaction was conducted with the bovine primers: BTCOIF11 and BTCOIR11 with the DNA isolated from meat products. Individual lanes were marked with the numbers which correspond to particular sample - see Materials and Methods chapter. Letter abbreviations: PC - positive control sample, HS - human DNA, NTC negative control sample, MW - size marker.

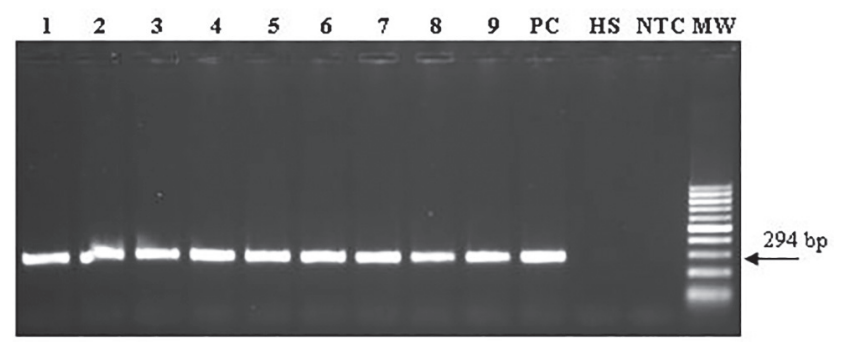

FIGURE 2. The electrophoretic separation of PCR products in $1 \%$ agarose gel. A polymerase chain reaction was conducted with the pig primers: SSCOIF11 and SSCOIR11 with the DNA isolated from meat products. Description of particular lines - see Figure 1.

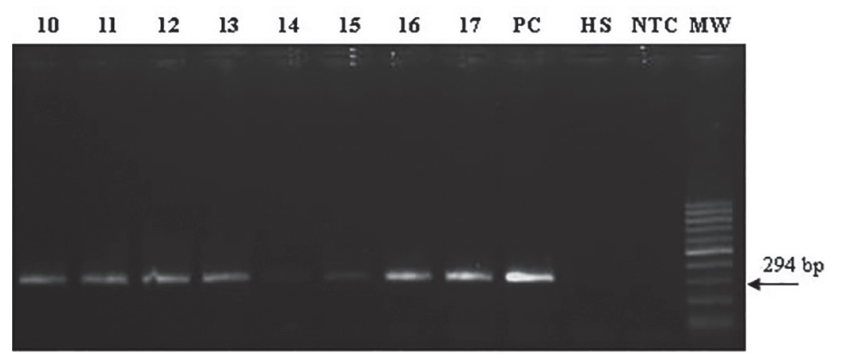

FIGURE 3. The electrophoretic separation of PCR products in $1 \%$ agarose gel. A polymerase chain reaction was conducted with the pig primers: SSCOIF11 and SSCOIR11 with the DNA isolated from meat products. Description of particular lines - see Figure 1.

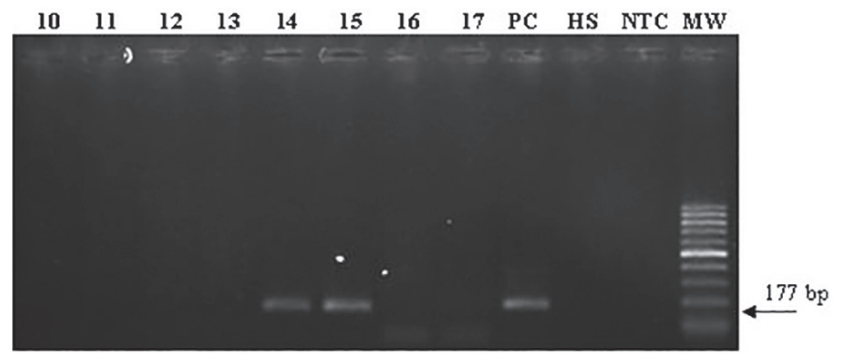

FIGURE 4. The electrophoretic separation of PCR products in $1 \%$ agarose gel. A polymerase chain reaction was conducted with the duck primers: APCOIF11 and APCOIR11 with the DNA isolated from meat products. Description of particular lines - see Figure 1. process applied in the production of cold cuts. DNA may be partly degraded as a result of the standard procedures applied in the manufacturing process of meat products (e.g. boiling, sterilisation). In some cases, the fragmentation of DNA may lead to the development of a background or it may even make it impossible for a PCR product to be formed, which makes the analysis more difficult [Musto, 2011].

Also, certain environmental factors (low $\mathrm{pH}, \mathrm{UV}$ radiation, humidity) may cause a chemical modification of the DNA particle, resulting in its fragmentation or in the formation of PCR artefacts. In consequence, this may cause the appearance of misleading results [Teletchea et al., 2005].

This part of the research included analysis of the ability of the designed PCR primers to identify the bovine, pig and duck DNA in 17 meat products. Some products contained considerable amounts of fat and other additives, which are routinely applied in the technological process, according to the rules of good manufacturing practices. In pâtés, the content of fat usually amounted to about $20 \%$, whereas in finely minced products, such as Vienna sausages, the fat content reached about $35-40 \%$. It is noteworthy that in the production process the meat underwent various technological treatments, such as salting, curing, smoking, cooking, pre-drying or even sterilisation. The PCR which was conducted with the use of bovine-specific primers with the DNA acquired from 17 meat products showed that the bovine DNA could be found in samples 10-13, which was in agreement with the ingredients declared by manufacturers on product labels (Figure 1).

The analysis of meat products for pork content proved that this type of meat could be found in all of the samples under investigation, i.e. 1-17, except sample number 14. As a rule, it was in agreement with the manufacturers' statements (Figures 2, 3). According to the manufacturer's declaration, there was no pig meat in sample ' 8 ', but the list of ingredients included pig fat, which may have contained elements of the pig muscle tissue. This status quo probably affected the result.

A pair of primers specific to the duck DNA proved that the DNA of this animal was present in samples '14' and ' 15 ' (Figure 4). Whereas the presence of the duck DNA in sample '14' is justified, the presence of this DNA in sample ' 15 ' proves that it was added deliberately, which means that it was used as a substitute or to adulterate the product. As was proved in earlier stages of the research, i.e. during the reactions with the DNA from raw duck meat and raw meat mixtures, the primers designed for the duck were specific only to the duck DNA. Thus, a cross-reaction could not have taken place here, but part of the goose meat was deliberately replaced with duck meat.

In this research, the primers hybridising with the bovine, pig and duck DNA proved full species specificity. The obtained results also point to the fact that a PCR product can be obtained not only from raw products but also from the products which underwent cooking, roasting or even sterilisation.

Apart from that, the selected DNA isolation method resulted in obtaining the appropriate quality of DNA specimens, which were free from the contaminants which may have made it difficult to obtain reliable results. 
The usefulness of the COI gene and scientists' interest in using its sequences for the identification of animal DNA is proved by the research by Natonek-Wiśniewska et al. [2013]. Their findings indicated the feasibility of detecting $0.09 \%$ of the pig DNA in feeds made from both vegetable and animal raw materials by means of PCR primers designed on the basis of the COI gene sequence.

To sum up, the results of this study and the findings of other authors' studies [Herbert et al., 2003; Wong \& Hanner, 2008; Dalton \& Kotze, 2011; Dawnay et al., 2007; Pereira et al., 2008; Feligini et al., 2005, 2007; Haider et al., 2012; NatonekWiśniewska et al., 2013] give grounds for the conclusion that $C O I$ gene sequences are very useful for analyses related with the identification of species in the meat of slaughter animals, conducted by means of the methods of molecular biology.

\section{CONCLUSIONS}

The findings presented in this study confirmed the fact that it is possible to identify the meat of three species of animals, i.e. bovines, pigs, and ducks, on the basis of the COI gene sequence. All the three sets of designed primers showed full specificity for the bovine, pig and duck DNA sequences, respectively. It was possible to conduct species-specific amplification not only from the samples where DNA came from raw meat but also from those where it came from mixtures and processed meat products. The developed method can be a useful tool for meat species detection tests. This study needs to be continued to estimate sensitivity level, i.e. the lowest amount of meat species which can be identified in meat products by application of self-designed PCR primers.

\section{ACKNOWLEDGEMENTS}

This work was financially supported by grant N N312 205636 from the Polish Ministry of Science and Higher Education.

\section{REFERENCES}

1. Ballin N.Z., Vogensen F.K., Karlsson A.H., Species determination - Can we detect and quantify meat adulteration? Meat Sci., 2009, 83, 165-174.

2. Cammà C., Di Domenico M., Monaco F., Development and validation of fast real-time PCR assay for species identification in raw and cooked meat mixtures. Food Contr., 2012, 23, 400-404.

3. Dalton D.L., Kotze A., DNA barcoding as a tool for species identification in three forensic wildlife cases in South Africa. Forensic Sci. Int., 2011, 207, 51-54.

4. Dawnay N., Ogden R., McEwing R., Carvalho G.R., Thorpe R.S., Validation of the barcoding gene COI for use in forensic genetic species identification. Forensic Sci. Int., 2007, 173, 1-6.

5. Eaqub Ali M., Kashif M., Uddin K., Hashim U., Mustafa S., Bin Che Man Y., Species authentication methods in food and feeds: the present, past and future of halal forensics. Food Anal. Method, 2012, 5, 935-955.

6. Fajardo V., González I., López-Calleja I., Martín I., Hernández P.E., García T., Martín R., PCR-RFLP authentication of meats from red deer (Capreolus capreolus), cattle (Bos taurus), sheep (Ovis aries), and goat (Capra hircus). J. Agr. Food Chem., 2006, 54, 1144-1150.

7. Fajardo V., González I., Rojas M., García M., Martín R., A review of current PCR-based methodologies for the authentication of meats from game animals species. Trends Food Sci. Tech., 2010, 21, 408-421.

8. Feligini M., Bonizzi I., Curik V.C., Parma P., Greppi G.F., Enne G., Detection of adulteration in Italian mozzarella cheese using mitochondrial DNA templates as biomarkers. Food Technol. Biotechnol., 2005, 43, 91-95.

9. Feligini M., Alim N., Bonizzi I., Enne G., Aleandri R., Detection of cow milk in water buffalo cheese by SYBR Green realtime PCR: sensitivity test on governing liquid samples. Pakistan J. Nutr., 2007, 6, 94-98.

10. Gil L.A., PCR-based methods for fish and fishery products authentication. Trends Food Sci. Tech., 2007, 18, 558-566.

11. Haider N., Nabulsi I., Al-Safadi B., Identification of meat species by PCR-RFLP of the mitochondrial COI gene. Meat Sci., 2012, 90, 490-493.

12. Herbert P.D.H., Cywinska A., Ball S.L., deWaard J.R., Biological identifications through DNA barcodes. Proc. R. Soc. Lond. B, 2003, 270, 313-321.

13. Iwobi A.N., Huber I., Hauner G., Miller A., Busch U., Biochip technology for the detection of animal species in meat products. Food Anal. Method, 2011, 4, 389-398.

14. Kalak R., Pławski A., Lipiński D., Jura J., Juzwa W., Słomski R., Przygotowanie produktów PCR do sekwencjonowania (Preparation of PCR products for sequencing). 2004 in: Przykłady analiz DNA [Examples of DNA analysis] (ed. R. Słomski). Wyd. Akademii Rolniczej im. Augusta Cieszkowskiego w Poznaniu, pp. 283-286 (in Polish).

15. Karabasanavar N.S., Singh S.P., Umapathi V., Kumar D., Shebannavar S.N., Identification of goat meat using highly species-specific polymerase chain reaction. J. Food Qual., 2011, 34, 142-149.

16. Musto M., DNA quality and integrity of nuclear and mitochondrial sequences from beef meat as affected by different cooking methods. Food Technol. Biotech., 2011, 49, 523-528.

17. Natonek-Wiśniewska M., Krzyścin P., Piestrzyńska-Kajtoch A., The species identification of bovine, porcine, ovine and chicken components in animal meals, feeds and their ingredients, based on COX I analysis and ribosomal DNA sequences. Food Contr., 2013, 34, 69-78.

18. Partis L., Croan D., Guo Z., Clark R., Coldham T., Murby J., Evaluation of a DNA fingerprinting method for determining the species origin of meats. Meat Sci., 2000, 54, 369-376.

19. Pereira F., Carneiro J., Amorim A., Identification of species with DNA-based technology: current progress and challenges. Recent Pat. DNA Gene Sequence, 2008, 2, 187-200.

20. Sambrook J., Russell D.W., DNA sequencing. 2001, in: Molecular Cloning: a laboratory manual, 3rd edn. (eds. J. Sambrook, D.W. Russell). Cold Spring Harbor Laboratory Press, New York, pp. 12.1-12.9.

21. Statistical Yearbook of Agriculture (Rocznik Statystyczny Rolnictwa), 2013, Wyd. Główny Urząd Statystyczny. Zakład Wydawnictw Statystycznych, Warszawa, p. 198 (in Polish).

22. Teletchea F., Maudet C., Hänni C., Food and forensic molecular identification: update and challenges. Trends Biotechnol., 2005, 23, 359-366. 
23. Wilson I.G., Inhibition and facilitation of nucleic acid amplification. Appl. Environ. Microb., 1997, 63, 3741-3751.

24. Wong E.H.K., Hanner R.H., DNA barcoding detects market substitution in North American seafood. Food Res. Int., 2008, 41, 828-837.
Submitted: 21 January 2015. Revised: 6 July 2015. Accepted: November 2015. Published on-line: 21 January 2016. 